\title{
“Charanga Cakewalk": Tejano Music Takes Center Stage
}

\author{
Claude CHASTAGNER \\ Université Paul-Valéry, Montpellier 3, France \\ Department of English \\ claude.chastagner@univ-montp3.fr
}

\begin{abstract}
This paper explores the sounds of the Tejano community, and probes to what extent the musical production of a given ethnic group is constitutive of a global American sound, or if on the contrary, it serves to foster the interests and the leverage of the said group, unraveling in the process the very notion of a unified American culture. The study is based on the work of Michael Ramos, founder and leader of the influential band Charanga Cakewalk, a Tejano musician with typically strong roots both in the Mexican and in the US communities. The music of Charanga Cakewalk, which draws equally from the Latino and Anglo idioms, while mixing old school genres with contemporary experimentations, helps to assess the impact of staging subversive sounds that dislocate the dominant ones.
\end{abstract}

Keywords: Tejano music, Chicano music, Charanga Cakewalk, Michael Ramos, Latino music

To a greater extent than most Western countries, the United States is associated to specific musical sounds, which have come to play a central role in defining Americanness. Many different communities, be they ethnic, regional, or class based, have used popular music to display key symbolic features of their identities and stage aural representations of the image they have of themselves, or they wish to project. American popular music is commonly equated with rock, blues, jazz, country, and rap, and their many sub-genres, i.e., sounds commercially successful not only within the country, but also across the borders. However, these idioms are only a fragment, albeit the most conspicuous, of the popular sounds staged in the United States. Other, less widespread genres, often dubbed "ethnic," have from their inception enjoyed regional success. They correspond to what Ani DiFranco calls "the undercurrent of organically generated music" (1999: 9). Many of these styles have their origin outside Anglo-American or African-American communities: chicken scratch, the music of the Tohono O'odham; Hawaiian slack-key guitar; the decima of the Isleños, immigrants from the Canary Islands living in the Mississippi delta; bhangra, an off-shoot of the Indo-Pakistani diaspora, whose roots are both in India and Great-Britain; Cajun and zydeco, in Francophone Louisiana; salsa, rooted in the Cuban, Puerto-Rican, and Dominican immigration; klezmer, originally from Jewish circles; the polkas and tamburitzas of the Scandinavian and Central and Eastern European communities of 
the upper Midwest; the sounds of the various East, and Southeast Asian groups, from Korean rap to Chinese jazz, to name just a few.

Out of this mosaic, the music of the Mexican-Americans, the largest Latino community in the United States, 28 million out of 52 million Latinos, has surprisingly remained confidential. It never had the success, nor the impact of Afro-Cuban styles such as the mambo, the rumba, the bolero, salsa, or Latin jazz. One potential explanation could be that Mexican-American music (and the Mexican traditions from which it originates) displays fewer African elements. Indeed, it is rather a combination of Spanish canciones with Indian, German, Polish, and Italian idioms and rhythms, which evolved during the twentieth century into specific styles: orquestas de cuerdas, orquestas tejanas, bandas, conjuntos, grupos, and Tejano, several, as their names show, originating in Texas. These various musical styles, although essential components of the Mexican-American identity, proved less popular outside the community than African-influenced idioms, with the exception of Mariachi ensembles, who came to epitomize Mexican music for most Anglo Americans, and contributed to spreading the cliché of the sombrero wearing, siestaprone charro.

There were a few attempts at breaking this pattern, mostly in California. In the early 1950s, in Los Angeles, a Mexican form of boogie-woogie sung in caló, the language of the pachucos, the bad boys, became briefly, but intensely successful with the likes of Don Totsi and Lalo Guerrero. In 1958, Ritchie Valens had a surprising international hit with "La Bamba," one of the earliest occurrences of rock en español, but his untimely death cut short any potential development of the genre. In the mid 1960s, the Eastside Sound of Los Angeles bands like Thee Midniters or The Mendells, singing exclusively in English, enjoyed a modicum of success. One of these bands, Cannibal and the Headhunters, opened for the Beatles' second US tour. However, few outside the community were aware of their Mexican background which for most was kept carefully hidden. Eventually, in the late 1960s, in the wake of the Brown Power movement, from San Francisco and Los Angeles emerged the Chicano rock of artists like El Chicano, Tierra, or Malo. But their music owed more to AfroCuban salsa than to Mexican traditions, and again, apart from Santana, most did not become popular with national (and international) audiences. It is only recently that newer forms have crossed over and made their way into Anglo consciousness by simultaneously borrowing from Anglo and African-American idioms, and cultivating a lyrical or aural Mexican specificity. Three main styles have come to the fore: Chicano rap (Kid Frost, A Lighter Shade of Brown, Aztlán Underground), Chicano punk (Los Illegals, The Cruzados) and Chicano techno (Nortec Collective, Instituto Mexicano del Sonido).

The Tejanos, the 9 million Mexican-Americans living in Texas, as well as their compatriots living on the other side of the Texas border, have a distinct musical history. They developed several genres during the twentieth century, which have been very popular with Mexican-Americans: orquestas de cuerdas, orquestas tejanas, 
conjuntos, and grupos. Currently the music of the Tejanos falls into two main categories. On the one hand, there are the rustic sounds of conjunto, which have been enjoying a surprising revival and include mostly rancheras (country songs) and corridos (epic narratives). With its accordion-driven polkas and waltzes sung in Spanish by singers dressed in vaquero wear, conjunto definitely looks and sounds Mexican. On the other hand, one finds the very popular Tejano, or Música Tejana, a form of polished pop, sung in Spanish and English, and borrowing from Anglo styles like rock, country, or jazz. Many Anglos are not aware of these sounds: concerts and dances are mostly organized in Latino communities, the record stores where the music can be found are located in Chicano districts, and Tejano artists are rarely featured on mainstream Anglo radio or television programs. When in 2012 the Grammy Academy decided to suppress or consolidate from its lists of awards several categories of roots music, including Latin, mariachi, Tejano, banda, and Norteño, many artists went even further and considered the decision based on a racial bias that deemed the music as unsophisticated and unworthy as the community that produces it (see for instance Lewis and Schurmann).

However, a new generation of Tejano artists is gradually playing a more prominent role on the American musical stage, suggesting in the process an improved social positioning for the Tejano community as a whole. Using the example of Michael Ramos' band, Charanga Cakewalk, this article explores the interactions between the musical space and the social space that Tejanos currently occupy on the American stage. What do musical trends tell us? The present article shall first examine the changes occurring within the Tejano community, and in its relationship with the Anglo environment, in terms of changing image and new forms of militancy, before dealing with the cultural processes triggered or highlighted by the success of these sounds.

Michael Ramos, the founder of Charanga Cakewalk, was born in El Campo, a small community outside Houston, in the late fifties, and now lives in Austin, Texas. His parents were a middle class family of Mexican origin (his father was an electrician and later worked for the petro-chemical industry, and his mother worked as a secretary for governmental agencies), with "some Comanche and Irish blood," ${ }^{1}$ a fact which, though hardly audible in his music, is a testimony to the complex ancestry of many Mexicans-Americans and should prevent from any simplistic labeling of the community. He was a member of The BoDeans, a multi-ethnic American rock band, and has been, and still is, a sideman for famous Anglo rock artists such as Paul Simon, The Rembrandts, John Mellencamp, The Dixie Chicks, and, more recently, Robert Plant. He increasingly writes scores for movies. Since 2004, he has been recording his own music under the name of Charanga Cakewalk from his base in Austin: three albums so far, on which he plays most instruments, with a few guests.

\footnotetext{
${ }^{1}$ All the quotes by Michael Ramos are taken from a personal interview conducted by the author in November 2012.
} 
The growing success of Charanga Cakewalk points to a number of social mutations. Firstly, it hints at a lowering of class distinctions within the MexicanAmerican community. From the 40s onward, la gente decente (also called jaitón, for "high-tone"), the Mexican-American middle-class, considered la gente pobre and their cultural tastes an impediment to the integration of the community into Anglo mainstream society (Peña 2001: 39). As a consequence, upward mobile, urban, middle-class Mexican-Americans preferred the smooth, modern, jazzy sounds of orquestas rather than the archaic conjuntos to express their superiority to the rural working classes, the campesinos and vaqueros. From the 1970s onward, however, in the wake of the Chicano movement, middle-class Tejanos gradually changed their tastes. In a move similar to what had just happened in the African-American community, El Movimiento (the Brown Power movement which included groups such as La Raza Unida, MEChA, or the Brown Berets), had highlighted the importance of arts and culture as a means to define Mexican-American identity. Many Chicano rock bands of the era, for instance, adopted Inca and Aztec symbols as an affirmation of a common ethnic identity that transcended class. They called themselves El Chicano, Tierra, Santana, Malo, Sapo, or Azteca. The sleeves of their albums featured Mexican murals, Hernando Cortes, and vibrant manifestos. On Revolucion (1971), El Chicano's first album, for example, one can read: "El Chicano means The MexicanAmerican. It used to be that it was a put-down for a Mexican-American to be called a Chicano but, today, the new breed Mexican-American has learned to identify with the adjective in much the same way the Afro-American has learned to identify with Black". And on Tierra's eponymous album (1973): "Completely Chicano, that is Mexican-Americans with an awareness and pride in themselves and their heritage. Racially, most Chicanos are Mestizo, the combining of Indian and European elements into a new race - La Raza - and a rich cultural blend. The music of Tierra reflects this." In the Tejano community, where the impact of rock was less marked than in California, the middle classes gave up orquestas and adopted the working-class sounds of conjunto and Música Tejana. Tejano artists like Little Joe y Familia reached both the working- and middle-classes by combining Mexican ranchera sounds with polished Anglo pop.

Charanga Cakewalk goes one step further; the use of both traditional and cuttingedge instrumentation (accordion, quarto, harp, cavaquinho, bajo sexto, requinto, jarana, and computerized beats and loops) and rural and urban styles (boleros, mambos, but also polkas, corridos, and huapangos to which are added African \& Brazilian elements) allows Michael Ramos to appeal to all Mexican-Americans, old and young, urban and rural, middle and lower class, from Texas to Canada, and to draw together a socially varied community. Ramos is aware of the attraction he exerts: "I usually seem to win the audience over [...] The crowd would really enjoy and cheer, that made me feel very validated." His emphasis on cumbia (it is the name of both his studio and his second album, and a musical style he uses frequently) is in that respect revealing: cumbia has become a pan-Latino, trans-generational, trans- 
class music, to the same extent as bhangra has become the common denominator for the India-Pakistani diaspora.

The second mutation Charanga Cakewalk evinces is a lowering of ethnic distinctions between Mexican-Americans and Anglos. Michael Ramos' music does not emulate Anglo sounds to further Tejano integration into mainstream society the way orquesta music did in the 1950s; it does not conversely proffer a tool for ethnic resistance, like the Chicano rock of the 1970s; it does not either blend the Anglo and Chicano traditions in order to appeal to modern, urban, but also ethnically conscious Tejanos. What can be heard in his music is both more unassuming and more ambitious. The complex, culturally and socially mixed sounds of Charanga Cakewalk aim at being "American," at appealing to all communities, redefining in the process what is American popular music. They underscore complex intra- and inter-group exchanges and hybridization processes currently taking place in the United States. As Adelaida Reyes recalls, "[American] musics have been labeled as though they were single, culturally indivisible units. [...] Music, like the nation-state and its language, have been presumed governed by a single system" (2005: 11). But bands like Charanga now challenge these assumptions.

Ramos' bi-cultural, bi-musical background may account for this orientation: "I spoke Spanish fluently and almost exclusively at home as I was growing up, but I spoke English as well. I listened to the Top 40, the Beatles, the Rolling Stones, Led Zeppelin. We also listened to all the Mexican radio stations in Texas, so in the same day, we might be listening to conjuntos, polkas, and the next hour to the Beatles.” The seamless blending of different influences seems to have hit the mark: Charanga Cakewalk's music is now played on NPR and Anglo stations throughout the United States, they give concerts all over the country, including at prestigious, indie festivals like SXSW in Austin, which gives it a definite urban, contemporary, "white" aura. But at the same time, the band keeps on playing at Chicano dances or festivals throughout the country with equal success.

The band resorts to several strategies to implement its bi-musical style. To begin with, it bears a significantly composite name: a charanga is a Cuban and Spanish musical ensemble, while the cakewalk is an African-American dance. The titles of their albums are always bilingual: Loteria de la Cumbia Lounge, Chicano Zen, El Brown Recluse. They also usually host a combination of Mexican, Mexican American, and Anglo guests, such as Lila Downs, Martha Gonzales and Quetzal Flores, David Garza, Ruben Ramos, Celso Duarte, Max Baca, Patty Griffin, David Grissom. Eventually, the heterogeneous instrumentation already mentioned adds to the ambi-cultural flavor of the band. These strategies contribute to the coming together of different ethnic traditions.

A third mutation triggered by bands like Charanga is the new image they contribute to draw of Mexican-Americans. For years, like many of his peers, Michael Ramos had been ashamed of his Mexican heritage. As he affirms, 
If you spoke Spanish in school you were harshly disciplined. I determined that speaking Spanish and being Mexican was a bad, shameful thing. Growing up, I was trying to not stand out and draw attention to myself. I tried to keep the Mexican music away from my friends that weren't Mexicans, as it was a very embarrassing thing for me. If we were in the car, I would turn the music down or off. The accordion being the lead instrument in conjunto and Latin music at the time, I was even more ashamed of it. I tried to stay away from accordion music as much as possible.

The shame of having a Mexican background was compounded by the fact of wanting to hide it, a feeling that is still palpable. As Ramos has said, "I have always been sad that I let it go, but I had determined as a child, that speaking Spanish was a bad thing. I am ashamed to admit that now."

Significantly, Charanga Cakewalk is a way to get over the shame: "I do it to encourage other artists, young musicians, to be proud of their heritage and music, not be ashamed of it, or feel any lesser because of it," says Michael Ramos. Indeed, the sound of Charanga Cakewalk is at the same time Latino and elegant, ethnically grounded and technologically savvy; it is not associated to the stereotypes that plague the Chicano and Tejano communities: los cholos (an ethnic slur applied to members of various Chicano subcultures), la vida loca (a life of wild partying), crazy greasers, or lazy spics (terms disparaging Chicanos for their alleged laziness or lack of hygiene). On the contrary, Charanga Cakewalk's fusion of Latin with indie and lounge music has come to epitomize cutting-edge urban chic and cool. The liner notes and the lyrics reveal a spiritual dimension rarely associated to the Chicano community. Their second album is entitled Chicano Zen, two words rarely used together. Indeed, if Chicanos are often stereotyped as lazy, it has little to do with the elegant Japanese form of detachment and meditative state the word "zen" evokes.

These unusual connotations contribute to foster a new, sleeker image of Tejanos and a more positive appraisal of the community. Michael Ramos confirms: "I do feel we change a lot of people's stereotypes when they come to hear us play." Something comparable in nature (though dissimilar in direction) is happening with the narcocorrido culture of California, because of which, "for the first time since the United States took control of the Southwest, being Mexican-down-home, hillcountry, rancho-raised Mexican—is cool” (Wald 2001: 228).

New forms of cultural militancy also appear in the wake of Michael Ramos' band. Significantly, Ramos has not reached success at the cost of hiding his identity; on the contrary, he proudly displays his Chicano culture, but in new ways that pay heed to Serge Gruzinski’s admonition to Chicanos: “¿Si en lugar de cultivar una mexicanidad trasnochada, se pusieran a hablarnos de nosotros mismo al hablarnos de lo que son?” (2011: 63). ${ }^{2}$ This is exactly what Ramos does: through his music, he talks about

\footnotetext{
2 "If instead of cultivating an outmoded Mexicanity, they started to talk to us about ourselves when talking about who they are.”
} 
himself, but in ways that talk to the whole community. Admittedly, he harbors a remaining sliver of anger and resentment. Besides causes similar to those of recent immigrants, such as racism and economic exploitation, Tejanos have specific historical reasons to bear a grudge against the United States, dating back to the nineteenth century when their territory was forcefully annexed. While talking about his family history, Michael Ramos alludes to this larger historical perspective:

My family actually had land grants given to them by the queen of Spain; that land was confiscated from them and that has always been a sore spot with me. I never really felt rebellious growing up. [But when] I was older, I started listening again and revisiting all the music of my youth and part of me became resentful towards the prejudice and the hypocrisy and the segregation of my youth, it was very hard for me not to have a chip on my shoulder. I started to question why I was being put down; it still makes me angry.

One song particularly points towards classic forms of militancy, "El Ballad de Jose Campos Torres," about which Michael Ramos writes in the liner notes: "In 1976 a young Mexican kid was picked up by the police in Houston, TX. He was beaten, handcuffed, and thrown off of a bridge into the bayou, where he drowned. The officers were charged and fined a dollar and put on probation. All these years later, I find myself thinking of J. C. Torres.” Besides writing these unusually bitter lines, Ramos has penned a melancholy tune, washed over by heavy reverberation, that underlines the feelings of sadness and loss associated to the murder.

However, Charanga Cakewalk's militancy is not oppositional the way Chicano rock was. Rather than dwelling on his anger and resentment, Michael Ramos stresses positive values closely associated to the Chicano community, the emotions tied to memories and family life which has led to his rediscovery of the accordion, "a living, breathing instrument, [that] represents a lot of emotion.” Brian Cross stresses the importance of emotions in Chicano culture: "Chicanos are really fond of memories, los recuerdos [...] They want to think about the old days when they were with their parents" (1993: 204). One only needs to remember how in 1970 Little Joe changed the name of his band from Little Joe and the Latinaires to Little Joe y La Familia, to appreciate the potency of such values. In the liner notes of Chicano Zen, Michael Ramos writes about the smell of mimosa when he was ten, his mother cooking tortilla and Spanish rice, memories of warm summer nights going to the drive-in with his parents for a "Mexican movie night." He adds:

Mexican are prone to nostalgia, it has to do with the family unit, your parents, your siblings. [...] The adversity, the prejudice that happens in everyday lives, I think that has a tendency to draw you in close to those that you grew up with, those memories of childhood, they become stronger, maybe even more important as you grow older. Latinos always relate to my music, they say "Oh My God, it reminds me of growing up.” 
In the same spirit, some of the lyrics, which are all in Spanish, are nothing more than lists of words which have a strong emotional resonance for the Chicano community: padres, niños, amantes, sangre, familia, padrones, abuelos, tradición ("Chicano Zen”) or lists of traditional Latino music genres, huapangos, reggaeton, cumbia, mento, rancheras, polkas, flamenco, merengue, bolero, chacha, son tejano, samba, rumba, norteño, mambo ... ("La Mimosa"), while at other times, Michael Ramos does not hesitate to play with the romantic clichés associated to Latino music, writing a song with only three words: Corazón, amor, porqué ("El Indio"). In all cases, rather than articulate demonstrations or sloganeering, Ramos is content with subtle and light evocations, of the kind triggered by a mere word from the parent culture and language.

Eventually, what is at stake with Charanga Cakewalk is connected to new cultural and identity processes. Apart from the specifically social changes discussed previously, Charanga Cakewalk also obliquely suggests theoretical paths that may be used to account for what is happening on the border, and how contemporary Tejanos are making sense of their multicultural identities. According to Corinne Andersen, there are two strategies by which the "I" can assert itself within the universal subject: mimicry or fragmentation (2008: 31). I believe Michael Ramos, and a growing number of Tejano artists choose neither. Neither fragmented nor a slavish imitation of Western style, Ramos' music is a complex but united, seamless, coherent whole that manages to summon a perhaps idealized image of raíces (roots), but also alludes to the specific history, and the contemporary lives of Tejanos, people of Mexican origin but born and educated in the United States.

Sareee Makdisi's analysis of modernity can help us understand Ramos' music. For Makdisi, modernity, as the West has conceptualized it, is an elusive promise, a future rather than a present, "the promise of what turns out to be a perpetually deferred future happiness" (1995: 98). It is this conception Arab nationalist movements adopted in the late nineteenth century, which ran against the more traditionalist approach advocated by religious groups calling for "the reinvention of some vanished moment of past glory" (1995: 99). Makdisi advocates a "third way" modernity, neither a utopian future nor a nostalgic past, but one that focuses on the "highly unstable and contradictory present, one that defies the convenient and false reassurances of new and old political, religious, and literary dogmatisms" (1995: 99). He insists on the necessity to confront, here and now, the problems of relegated individuals or communities. A similar insistence on the present can be heard in Ramos' music. The modernity of Charanga Cakewalk is not an escapist promise, a fake dream, nor a nostalgic trip. It is an acknowledgment of the difficulties Tejanos encounter every day, and the affirmation they can be proud of who they are. It is a confrontation with their second rate status, and the affirmation they have reached a new, hip and key position in American culture. 
Obviously, the music of Charanga Cakewalk, like much of border culture, can also be read as yet another instance of processes of mestizaje, hybridization, and thus as a revealing example of our glocal, postmodern society. ${ }^{3}$ However, as is well known, the concept of hybridity is a contested terrain, used with different ideological undertones and political agendas. Returning to the classic distinction established by Mikhail Bakhtin helps clarify the stakes. Working in the realm of linguistics, Bakhtin distinguishes two types of hybridity: an organic one, where "the mixture remains mute and opaque" (1981: 360), and an intentional one, "which enables a contestatory activity, a politicized setting of cultural differences against each other dialogically" (Young 1995: 20). The first one is thus unconscious and unintentional, a fusion rather than a protestation, and proceeds through unreflective borrowings, appropriations, and exchanges; the second, on the other hand, is more politicized and conflictual, its purpose being to unmask the dominant, authorial voice, to generate a dialogue between a mélange of competing voices, this time not in order to attain their fusion, but on the contrary to highlight their differences and challenge positions of power.

Bakhtin's linguistic analysis can be transposed into the realm of art, and not just in literature. It can lead to an exploration of transnational cultures, of métis or creolized cross-border art forms. In his article "Música fronteriza/Border Music,” Manuel Peña writes: "As both Limón and Paredes have pointed out [...] the cultural output of the Anglo has been rather meager in comparison to that of the Mexican American, who has expended considerable symbolic energy on the interethnic encounter. The Mexican's intense expressive cultural activity vis-à-vis the Anglo may be the result of the former's subordinate position in the social order that prevails within the Southwest Border” (2004: 191). As Peña suggests, much of Mexican American cultural production can be analyzed as a response to and an outcome of their peripheral position, and as such possesses an intentional, oppositional quality, in the Bakhtinian sense. However, we can wonder to what extent Charanga Cakewalk is a similar case of intentional hybridity or if it leans rather towards the organic. Despite Michael Ramos' lingering resentment and some militant undertones, his music displays little of the politicized, conflictual dimension Bakhtin underlines; Ramos' goal is not to use Anglo idioms to reveal the oppressiveness of colonial or imperialist power. He suggests a different form of hybridity that requires to establish a new distinction, this time between the intentional and the deliberate. If his borrowing is deliberate, it is not intentional in Bakhtin's sense. It is conscious, but not in order to challenge or contest anything. On the contrary, it offers a pacified ethos, inclusive rather than confrontational, closer to the prophetic perspective expressed by Édouard Glissant and Patrick Chamoiseau:

\footnotetext{
${ }^{3}$ See for instance Alejandro Madrid for similar readings of Tijuana’s Nor-tec scene.
} 
The walls that are built today, in the name of terrorism, uncontrolled immigration, or a favorite God, are not built between civilizations, cultures, or identities, but between poverty and overabundance, between wealthy but worried opulence and suffocating dryness. That is: between contradictions fueled by realities that globalized politics, with the adequate institutions, could manage, alleviate, even perhaps solve. The arts, literature, music and songs create a brotherhood through imaginary paths that have no longer anything to do with national geographies or languages so proud of their specificity. (2007: 10, my translation)

Moreover, Homi Bhabha's developments of Bakhtin's concepts allow to go one step further in the analysis of Ramos' hybridity. For Bhabha, "the importance of hybridity is not to be able to trace two original moments from which the third emerges, rather hybridity [...] is the Third Space which enables Other positions to emerge" (1990: 211). Bhabha's shifting of the location of hybrid culture and identity from the two "original" cultures to a third, liminal space, displaces polar logic and obliterates the boundaries between binary concepts such as center and margin, Europe and the Third World, the civilized and the savage, the North and the South, capital and labor, the enlightened and the ignorant, power and dominance. In the process, in a move similar to what the rhizomorphic theory of cultural flows describes, roots and points of origin disappear, in a challenge to notions of purity or authenticity (Barker 2008: 423).

The concept of a third, liminal space is crucial to understand how new forms of music such as that performed by Charanga Cakewalk do actually function within and for bi-cultural communities, how they challenge the idea of an original purity, how they displace binary logic and the oppressive forms of power that come with it. Arnold Van Gennep delineates three stages in the liminal process: separation, marginalization, and reaggregation. In the first, the preliminal one, the initiand leaves behind his culture, family, and roots, and breaks with previous social and cultural practices. The second stage, the transitional one, involves "the creation of a tabula rasa, through the removal of previously taken-for-granted forms and limits" (Szakolczai 2009: 148). This middle stage "implies an actual passing through the threshold that marks the boundary between two phases" (2009: 141). It is the actual liminal moment and space. Finally, the third, postliminal phase is a moment of reincorporation into society but with a new identity, emerging as a new person.

The history of the Mexican community and of individuals like Michael Ramos matches the anthropological description given by van Gennep and Victor Turner of the liminal process. Charanga Cakewalk is an indicator that Tejano society is standing in the liminal, intermediary, "in-between" space, the space which for Bhabha "carries the burden of the meaning of culture" (1994: 56). More precisely, the concept of the "third space of enunciation locates the meaning of cultures in the 'inter' - the cutting edge of translation and negotiation, the in-between space" (1994: 38). As border music, Charanga Cakewalk refuses to encourage conflicting dualities and exemplifies 
a will to move from fixed, established positions towards more complex, fluid, and less oppressive spaces. Bhabha has made us aware that fixed positions are "an important feature of colonial discourse [...] in the ideological construction of otherness" (1983: 19). Charanga's fluid moves are indicative of a refusal of the oppressive colonial logic, and of the growing ambicultural skills of the Mexican American community: rare, precious skills for a new modernity.

In his book devoted to Los Angeles, Edward Soja offers a complement to the liminal and Third Space theory that allows an even more precise understanding of how recent Tejano music is shaping and fostering new identities, and empowering the community. Instead of focusing on the difference, the "otherness" of diasporic subjects, he highlights their creativeness, their agency, and offers a prism by means of which the music of bands such as Charanga Cakewalk can be apprehended: not quirky and trivial epiphenomena, but the expected and exciting outcome of predictable evolutions. For Soja, in Third Space

everything comes together [...] subjectivity and objectivity, the abstract and the concrete, the real and the imagined, the knowable and the unimaginable, the repetitive and the differential, structure and agency, mind and body, consciousness and the unconscious, the disciplined and the transdisciplinary, everyday life and unending history. (1996: 57)

The link between the unpretentious notes and words of Charanga Cakewalk and the momentous impacts described by Soja may seem fairly farfetched, but beyond the innocent and unassuming pleasures provided by Michael Ramos and his likes, such processes are actually taking place, gradually and gently displacing traditional forms of power and oppression.

There are inherent limits to the possibilities opened up by liminal situations. If they do allow to supersede essentialist or polar positions, and to strengthen the expression of difference thanks to fluid cultural constructions, they can also lead to mimetic behaviors. As Horvath et al. state, "a central characteristic of liminal situations is that, by eliminating the stable boundary lines, they contribute to the proliferation of imitative processes and thus to the continuous reproduction of dominant messages about what to copy" (2009: 55). The unobtrusive, but bland and copycat sounds of much of "world music" is an instance of such mimetic behaviors. But in their subtlety and complexity, Charanga Cakewalk evade such pitfalls.

One final mutation triggered by Charanga Cakewalk has to do with the nature of the intercultural relations between the Tejano and Anglo communities, and the development of processes of transculturation, rather than acculturation, between the two groups. The most popular current model of intercultural strategies distinguishes four types of behaviors (Berry 1997: 10): marginalization, when individuals reject both the dominant/host culture and their own; separation, when individuals reject the dominant/host culture, but preserve their own; integration, when individuals adopt the 
dominant/host culture, and preserve their own (a form of bi-, or ambiculturalism); and assimilation, in which individuals adopt the dominant/host culture and reject their own. However, other possibilities can be suggested. In reaction to postmodern studies, for which "all knowledge is insecure and relative" (Gohrisch 2006: 231), cultural exchange studies focus on the local, the regional; they determine who the agents of cultural exchange are and highlight their different and complex backgrounds and affiliations. The focus on the cross-cultural exchanges that result from such careful examination allows an exploration of the reasons why specific cultural elements are being selected for exchange, why they are appropriated by both sides, and what new functions they are endowed with in their new environments. Consequently, as Gohrisch suggests, "rather than concentrating on acculturation, research should now center on transculturation, i.e. the shared or connected history of two or more ethnic groups and the adaptation of the borrowed cultural elements to the needs of those who borrow them" (2006: 234).

The term "transculturation" was coined in the 1940s by Cuban ethnologist Fernando Ortiz to overcome the lack of precision of the concept of acculturation. In Cuban Counterpoint, Tobacco and Sugar, he describes the various settlers of the island (from Paleolithic Indians to Spaniards, Africans, Jews, Portuguese, AngloSaxons, French, North Americans, and even migrants from Macao or Canton), as having been faced with "the problem of disadjustment and readjustment, of deculturation and acculturation - in a word, of transculturation" (1947: 97). The cultural processes taking place between the migrant and the host culture were a twoway exchange; each new migrant culture brought new elements to the host culture and the outcome, through the three-step process of deculturation, acculturation, neoculturation, was an original cultural form: "the offspring always has something of both parents but is always different from each of them" (1947: 103). Transculturation thus puts the emphasis on processes of borrowing, displacements, give-and-take, and reciprocity, and the emergence of original forms as a result, such as what happened in Cuba regarding music, and the sugar and tobacco industry. The concept of transculturation is a particularly apt tool to understand the nature of the cross-cultural mutation Charanga Cakewalk is implementing, and to analyze their impact on American music.

However, we need to qualify the suggestion that the cultural exchanges as a whole between Tejanos and el otro lado, "the other side," have led to significant transcultural processes. Mainstream American culture has integrated little of what their "hosts" have to offer, and apart from the musical forms mentioned above, few genuinely new transcultural products have emerged, combining in original ways Mexican and American influences. One could mention bands like The Texas Tornadoes, perhaps, or the celebration of Americanized real or pseudo Mexican events such as Días de los Muertos, or Cinco de Mayo, or yet the development of Tex-Mex food. But for the time being, most exchanges between the two communities 
have remained one-way processes, resulting mostly in the incorporation by Tejanos of cultural signs of the dominant culture.

Nevertheless, as this article has tried to demonstrate, Tejanos are now developing new cultural forms that gradually and imperceptibly transform and redefine American music and culture at large. For long, Tejanos had remained second-tier cultural agents. With bands like Charanga Cakewalk, they are now moving center stage.

\section{REFERENCES}

Andersen, Corinne (2008). Representing the Subject: An Interdisciplinary Study of Women's Autobiography, Self-portraiture, and Autoethnography in the Twentieth Century. Sarrebrück: VDM Publishing.

Bakhtin, Mikhail (1981). The Dialogic Imagination: Four Essays. Austin: U of Texas P.

Barker, Chris (2008). Cultural Studies, Theory and Practice. London: Sage.

Berry, John W. (1997). Immigration, Acculturation, and Adaptation. Applied Psychology 46(1): 5-34.

Bhabha, Homi (1983). The Other Question... Homi K. Bhabha Reconsiders the Stereotype and the Colonial Discourse. Screen 24(6): 18-36.

Bhabha, Homi (1990). Nation and Narration. London: Routledge.

Bhabha, Homi (1994). The Location of Culture. London: Routledge.

Browne, Ray, ed. (1966). New Voices in American Studies. Lafayette: Purdue UP.

Cross, Brian (1993). It's Not About a Salary... Rap, Race, and Resistance in Los Angeles. New York: Verso.

DiFranco, Ani (1999). Preface. In Wald, Elijah and John Junkerman, 9.

Glissant, Édouard and Patrick Chamoiseau (2007). Quand les murs tombent. L'identité nationale hors-la-loi ? Paris: Galaade.

Gohrisch, Jane (2006). Cultural Exchange and the Representation of History in Postcolonial Literature. European Journal of English Studies 10: 231-247.

Gruzinski, Serge (2011). 'I Offer You Explanations of Yourself' Globalizing Mexican Art to Resist the Present. Resisting the Present, Mexico 2000-2012. Paris: Paris-Musées; Mexico: Fundación Amparo: 302-307.

Horvath, Agnes, Bjørn Thomassen, and Harald Wydra (2009). Introduction: Liminality and Cultures of Change. International Political Anthropology 2(1): 3-4.

Lewis, Randy (2012). Grammy Awards: Musicians Will Protest Category Reductions. Los Angeles Times, 11 Feb.: n.p.

Madrid, Alejandro L. (2011). Transnational Encounters: Music and Performance at the U.S.-Mexico Border. New York: Oxford UP.

Makdisi, Saree (1995). 'Postcolonial' Literature in a Neocolonial World: Modern Arabic Culture and the End of Modernity. boundary 2 22.(1) (Spring): 85-115. Ortiz, Fernando (1947). Cuban Counterpoint: Tobacco and Sugar. New York: Knopf. 
Peña, Manuel (2001) From Ranchero to Jaitón. In Tejeda, Juan and Avelardo Valdez, eds., 31-61.

Peña, Manuel (2004). "Música fronteriza / Border Music.”Aztlán: A Journal of Chicano Studies 21(1-2): 191-225.

Reyes, Adelaida (2005). Music in America. Experiencing Music, Expressing Culture. New York: Oxford UP.

Ross, Stanley (1978). Views across the Border: The United States and Mexico. Albuquerque: $U$ of New Mexico P.

Rubin, Rachel and Jeffrey Melnick, eds. (2001). American Popular Music, New Approaches to the Twentieth Century. Amherst: U of Massachusetts P.

Szakolczai, Arpad (2009). Liminality and Experience: Structuring Transitory Situations and Transformative Events. International Political Anthropology 2(1): 141-172.

Soja, Edward (1996). Thirdspace: Journeys to Los Angeles and Other Real-andImagined Places. Oxford: Basil Blackwell.

Schurmann, Peter (2012). Grammy Awards Eliminates Roots Music - 'A Way to Kill Off Culture'? New America Media. $<$ http://newamericamedia.org/2012/02/grammy-awards-eliminates-roots-music--a-way-to-kill-off-culture.php> (Accessed 13 February 2012).

Tejeda, Juan and Avelardo Valdez, eds. (2001). Puro Conjunto, An Album in Words and Pictures. Austin: Center for American Studies Books.

Wald, Elijah (2001). Polka Contrabandista. Mexican Ballads in the Modern Age. In Rubin, Rachel and Jeffrey Melnick, eds., 211-231.

Wald, Elijah and John Junkerman (1999). River of Song. A Musical Journey Down the Mississippi. New York: St Martin's Press.

Young, Robert, J. C. (1995). Colonial Desire: Hybridity in Theory, Culture, and Race. London: Routledge. 